\title{
Lepidepyrone, a New $\gamma$-Pyrone Derivative, from Neolentinus lepideus, Inhibits Hyaluronidase
}

\author{
Tomoo Hosoe, Hideo Sakai, Makoto Ichikawa, Takeshi Itabashi, Takayuki Ishizaki, \\ Ken-ichi Kawai
}

Received: March 7, 2007 / Accepted: May 29, 2007

(C) Japan Antibiotics Research Association

\begin{abstract}
In the course of screening for hyaluronidase (HAase) inhibitory agents, a new $\gamma$-pyrone derivative, lepidepyrone, $\mathrm{C}_{8} \mathrm{H}_{10} \mathrm{O}_{5}$, was isolated from the cultured mycelium of the mushroom Neolentinus lepideus TMC1102 as a major HAase inhibitory compound $\left(\mathrm{IC}_{50}\right.$ $3.3 \mathrm{mM}$ ). The structure of lepidepyrone was established on the basis of spectroscopic investigation.
\end{abstract}

Keywords Neolentinus lepideus, $\gamma$-pyrone derivative, lepidepyrone, hyaluronidase inhibitor

The glycosaminoglycan, hyaluronan (hyaluronic acid; HA), which consists of repeating disaccharide units of $(\beta, 1-4)$-Dglucuronic acid and $(\beta, 1-3)-N$-acetyl-D-glucosamine, is a major component of the extracellular matrix of animal tissues. It is present in the skin (dermis and epidermis), brain, and central nervous system in significant quantitities [1].

Hyaluronidases (HAases) are enzymes that degrade HA. The mammalian HAases are present in many tissues and organs, e.g. liver, kindney, testes, etc. and are considered to be involved in many physiological processes like fertilization, tumor growth, and metastasis. Therefore HAase inhibitors could be useful as drugs, e.g. in the

T. Hosoe (Corresponding author), H. Sakai, M. Ichikawa, T. Itabashi, K. Kawai: Faculty of Pharmaceutical Sciences, Hoshi University, Ebara 2-4-41, Shinagawa-ku, Tokyo 142-8501, Japan, E-mail: kawai@hoshi.ac.jp

T. Ishizaki: Tamagawa University Research Institute, TamagawaGakuen 6-1-1, Machida, Tokyo 194-8610, Japan treatment of arthritis or degenerative disease in combination with antibiotics, and/or in antibacterial therapy of HA lyase producing bacteria, such as Streptococcus pneumoniae, a major human Gram-positive pathogen [2].

In our search for new HAase inhibitors from Japanese basidiomycetes, the extract from the cultured mycelium of Neolentinus lepideus (Japanese mushroom name: Matsuouji) TMC 1102 showed a potent inhibitory activity against HAase. The separation of the above extract led us to isolate a new $\gamma$-pyrone derivative designated lepidepyrone (1) along with methyl isoferulate (methyl 3-hydroxy-4methoxycinnamate) [3] and ergosterol. In this paper we have reported the structure determination and the inhibitory activity against HAase of $\mathbf{1}$.

The molecular formula of $\mathbf{1}$ (Fig. 1) was confirmed as $\mathrm{C}_{8} \mathrm{H}_{10} \mathrm{O}_{5}$ by high resolution chemical-ionization mass spectrometry (HRCI-MS). The UV absorption maximum at $252 \mathrm{~nm}$ of 1 suggested the presence of $\gamma$-pyrone class of compounds [4], whereas the IR absorptions maxima at $3400 \sim 3200 \mathrm{~cm}^{-1}$ and $1660 \mathrm{~cm}^{-1}$ revealed the presence of hydroxyl and conjugated carbonyl functions, respectively. The ${ }^{1} \mathrm{H}-\mathrm{NMR}$ spectrum of $\mathbf{1}$ showed the presence of two olefinic protons at $\delta 6.41$ (brs) and 8.06 (d), which suggested that the $\gamma$-pyrone ring was substituted with two aliphatic side chains. The substituent residues were hydroxymethyl group [ $\delta 4.42$ (s)] and 1,2-dihydroxyethyl group $[\delta 3.52(\mathrm{dd}), 3.78(\mathrm{dd})$, and $4.77(\mathrm{ddd})]$. The<smiles>O=c1cc([12CH]O)occ1[C@H](O)CO</smiles>

Fig. 1 Structure of lepidepyrone (1). 


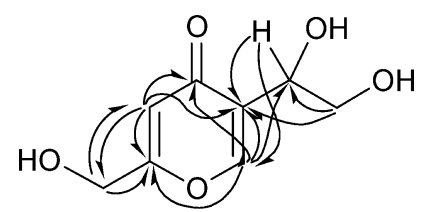

Fig. $2 \mathrm{HMBC}$ correlation of lepidepyrone (1).

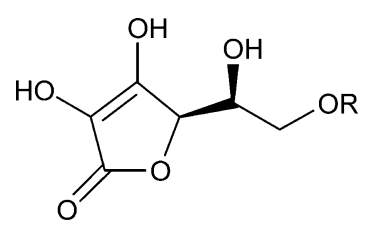

$$
\begin{aligned}
& 2: \mathrm{R}=\mathrm{H} \\
& 3: \mathrm{R}=\mathrm{CO}\left(\mathrm{CH}_{2}\right)_{8} \mathrm{CH}_{3} \\
& 4: \mathrm{R}=\mathrm{CO}\left(\mathrm{CH}_{2}\right)_{14} \mathrm{CH}_{3} \\
& 5: \mathrm{R}=\mathrm{CO}\left(\mathrm{CH}_{2}\right)_{16} \mathrm{CH}_{3}
\end{aligned}
$$

Fig. 3 Structures of ascorbic acid (2) and its 6-O-acylated derivatives.

positions of these side chains on the $\gamma$-pyrone ring were finally determined by the analysis of the HMBC spectrum as shown in Fig. 2. Therefore the structure of lepidepyrone was confirmed as shown in $\mathbf{1}$ (Fig. 1). The stereochemistry of $\mathbf{1}$ could not yet be determined.

The inhibitory effects on HAase were determined according to the literature [5]. The $\mathrm{MeOH}$ extract of $N$. lepideus TMC 1102 showed the inhibition of $25.7 \%$ at the concentration of $2.0 \mathrm{mg} / \mathrm{ml}$. The inhibitory activity was raised to $75.7 \%$ at $2 \mathrm{mg} / \mathrm{ml}$ after the above extract was extracyed with $\mathrm{BuOH} .1$ was the main component isolated from $\mathrm{BuOH}$ extract by the repeated purification of LPLC and HPLC. The inhibitory activity of $\mathbf{1}$ for HAase was determined as $\mathrm{IC}_{50} 3.3 \mathrm{mM}$, whereas $\mathrm{IC}_{50}$ value of cathechin as a positive compond was determined to $1.7 \mathrm{mM}$ (Table 1). L-Ascorbic acid (vitamin C; 2) showed weak inhibitory activity ( $\mathrm{IC}_{50} 6.1 \mathrm{mM}$ ) on HAase (HA lyase) from Streptococcus pneumoniae [7], but 2 did not show any inhibitory activity on bovine testicular HAase up to $100 \mathrm{mM}$ [2]. The inhibitory activities of 6-O-acylascorbic acid $(\mathbf{3} \sim \mathbf{5})$ on mammalian HAase showed stronger in accordance with the length of the side chain [6-decanoate (3): $\mathrm{IC}_{50} 1.4 \mathrm{mM}$, 6-hexaecanoate (4): $\mathrm{IC}_{50} 57 \mu \mathrm{M}$, 6octadecanoate (5): $\mathrm{IC}_{50} 39 \mu \mathrm{M}$ ]. It is interesting that $\mathbf{1}$ showed still weak inhibitory activity on mammalian HAace and 6-O-acylascorbic acid (4 and 5) showed the strong inhibitory activity in consideration with the structural similarity between $\mathbf{1}$ and $\mathbf{2}$.
Table 1 Inhibition of hyaluronidase (HAase)

\begin{tabular}{lc}
\hline \multicolumn{1}{c}{ Compound } & $\mathrm{IC}_{50}$ on HAase $(\mathrm{mM})$ \\
\hline Lepidepyrone (1) & 3.3 \\
L-Ascorbic acid (2) & $100^{[2]}$ \\
L-Ascorbic acid 6-decanoate (3) & $1.4^{[7]}$ \\
L-Ascorbic acid 6-hexaecanoate (4) & $0.057^{[2]}$ \\
L-Ascorbic acid 6-octadecanoate (5) & $0.039^{[7]}$ \\
Positive Compound (Cathechin) & 1.7 \\
\hline
\end{tabular}

\section{Experimental}

\section{General}

Melting points were determined on a Yanagimoto micromelting point apparatus and are uncorrected. CI-MS were taken with a JEOL JMS-MS600W spectrometer. UV and IR spectra were recorded on a Hitachi U-3210 spectrometer and a JASCO IR-810 spectrometer, respectivily. ${ }^{1} \mathrm{H}-$ and ${ }^{13} \mathrm{C}$-NMR spectra were recorded on a JEOL Lambda-500 $\left({ }^{1} \mathrm{H}, \quad 500 \mathrm{MHz} ;{ }^{13} \mathrm{C}, \quad 125 \mathrm{MHz}\right)$ spectrometer, using tetramethylsilane as an internal standard. CD curves were determined on a JASCO J-600 spectropolarimeter. Column chromatography was performed using Kieselgel 60 (Art. 7734, Merck) and Wakogel C-200 (Art. 237-00071, Wako). Low-pressure liquid chromatography (LPLC) was performed with a Chemco Low-Prep 81-M-2 pump and glass column $(200 \times 10 \mathrm{~mm})$ packed with Silica gel CQ-3 (30 50 $\mu \mathrm{m}$, Wako). HPLC was performed with a Senshu SSC-3160 pump (flow rate, $7 \mathrm{ml} /$ minute) and a YMC-Pack PEGASIL Silica $60-5(300 \times 10 \mathrm{~mm})$, equipped with a Shimamura YRD-883 RI detector. TLC were detected by UV light on $254 \mathrm{~nm}$ and/or by spraying with $5.0 \%$ phosphomolybdic acid - ceric acid (trace) in $5.0 \% \mathrm{H}_{2} \mathrm{SO}_{4}$ and then heating.

\section{Origin of Organisms}

$N$. lepideus retained as M-2721 by the Mushroom Research Institute of Japan, was found on a tree stump (Pinus densiflora) in hardwood forest in Gunma Prefecture, east Japan. The strain TMC-1102, which was isolated as a pure culture from the tissue of $N$. lepideus $\mathrm{M}-2721$, was used in this experiment.

\section{Fermentation, Extraction and Isolation}

$N$. lepideus TMC 1102 was cultivated on rice ( $570 \mathrm{~g}$ using 4 flasks) at $25^{\circ} \mathrm{C}$ for four weeks. The cultivated rice was extracted with $\mathrm{MeOH}$ and the organic layer was evaporated in vacuo. The residue ( $42 \mathrm{~g}$ ) was suspended in water and extracted with $\mathrm{BuOH}$. The organic layer was evaporated in 
vacuo to obtain the $\mathrm{BuOH}$ extract $(4.8 \mathrm{~g})$. The extract was purified by LPLC on silica gel column using $\mathrm{CH}_{2} \mathrm{Cl}_{2}$ $\mathrm{MeOH}(5: 1)$ to give 5 fractions. The second fraction $(1.5 \mathrm{~g})$ was purified by LPLC on silica gel using $\mathrm{CH}_{2} \mathrm{Cl}_{2}$ acetone $(60: 1)$ followed by further purification by HPLC on silica gel. $\left[\mathrm{CH}_{2} \mathrm{Cl}_{2}-\mathrm{Me}_{2} \mathrm{CO}(60: 1)\right.$ and/or benzene EtOAc $(7: 1)$ ] to give methyl isoferulate $(21 \mathrm{mg})$ and ergosterol $(95 \mathrm{mg})$. The third fraction $(0.44 \mathrm{~g})$ was further purified by HPLC on silica gel using $\mathrm{CH}_{2} \mathrm{Cl}_{2}-\mathrm{MeOH}$ $(60: 1)$ to obtain $1(217 \mathrm{mg})$.

\section{Physico-chemical Properties of 1}

Colorless amorphous solid. CI-MS $m / z$ (\%): 187.0611 $\left[(\mathrm{M}+\mathrm{H})^{+}, 187.0606\right.$ for $\left.\mathrm{C}_{8} \mathrm{H}_{11} \mathrm{O}_{5}\right]$. UV $\lambda_{\max }^{\mathrm{MeOH}} \mathrm{nm}(\log \varepsilon)$ : 213 (3.77), 252 (3.94). IR $v_{\max }$ (film) $\mathrm{cm}^{-1}: 3400 \sim 3200$ $(\mathrm{OH}), 2890,1660$ (conjugated $\mathrm{C}=\mathrm{O}), 1590,1440,1050$, 940, 870. $\mathrm{CD}(\mathrm{MeOH}) \Delta \varepsilon(\mathrm{nm}):-3.71(251),+3.26$ (293). $[\alpha]_{\mathrm{D}}^{25}-95^{\circ}$ (c 0.1, MeOH). ${ }^{1} \mathrm{H}-\mathrm{NMR}\left(\mathrm{CD}_{3} \mathrm{OD}\right) \delta$ $3.52(1 \mathrm{H}, \mathrm{dd}, J=11.5,5.8 \mathrm{~Hz}, 9-\mathrm{H}), 3.78(1 \mathrm{H}, \mathrm{dd}, J=11.5$, $3.4 \mathrm{~Hz}, 9-\mathrm{H}), 4.42(2 \mathrm{H}, \mathrm{s}, 7-\mathrm{H}), 4.77(1 \mathrm{H}, \mathrm{ddd}, J=5.8,3.4$, $1.2 \mathrm{~Hz}), 6.41(1 \mathrm{H}$, br s, 3-H), $8.06(1 \mathrm{H}, \mathrm{d}, J=1.2 \mathrm{~Hz}, 6-\mathrm{H})$. ${ }^{13} \mathrm{C}-\mathrm{NMR}\left(\mathrm{CD}_{3} \mathrm{OD}\right) \delta 61.0(\mathrm{C}-7), 65.8(\mathrm{C}-9), 68.4(\mathrm{C}-8)$, 112.4 (C-3), 129.6 (C-5), 155.7 (C-6), 171.2 (C-2), 180.7 (C-4).

\section{Assay of Inhibitory Effects on HAase [5]}

HA sodium salt from rooster comb (Wako Pure Chemical Industries Ltd., Osaka, Japan, $0.25 \mathrm{mg} / \mathrm{ml}$ ), HAase from bovine testes (Wako Pure Chemical Industries Ltd., Osaka, Japan), and compound 48/80 (Sigma Chemical Co. Ltd., St. Luis, U.S.A., $3.0 \mathrm{mg} / \mathrm{ml})$ containing $\mathrm{NaCl}(17 \mathrm{mM})$ and $\mathrm{CaCl}_{2}(27 \mathrm{mM})$ were dissolved in $0.1 \mathrm{M}$ acetate buffer $(\mathrm{pH}$ $4.0)$, respectively. The test samples were dissolved in dimethylsulfoxide for $\mathrm{MeOH}$ extract and $\mathrm{BuOH}$ extract $(2.0 \mathrm{mg} / \mathrm{ml})$ and in acetate buffer for $1(0.5 \sim 10 \mathrm{mM})$. $p$ Dimethylaminobenzaldehyde (Wako Pure Chemical Industries Ltd., Osaka, Japan, $20 \mathrm{mg} / \mathrm{ml}$ ) was dissolved in conc. $\mathrm{HCl}$ - acetic acid $(1: 39)$. All aqueous solutions were prepared using water filtered through a Milli-Q water system (Millipore, Belford, U.S.A.). All chemicals were of reagent grade.

HAace (460 units/ml, $130 \mu \mathrm{l}$ ), which had been preincubated with the test sample $(20 \mathrm{ml})$ at $37^{\circ} \mathrm{C}$ for 10 minutes in advance, was incubated with compound 48/80 $(100 \mu \mathrm{l})$ at $37^{\circ} \mathrm{C}$ for 10 minutes. After the incubation HA sodium salt $(250 \mu \mathrm{l})$ was added and the reaction mixture was incubated at $37^{\circ} \mathrm{C}$ for 40 minutes. Then the reaction was stopped by adding $0.4 \mathrm{M} \mathrm{NaOH}(100 \mu \mathrm{l})$, and then the mixture was allowed to stand for 10 minutes in ice water.
The inhibitory effect was determined by the modified Morgan-Elson method [6]. The reaction mixture was boiled for 3 minutes after adding borate buffer ( $\mathrm{pH} 9.1)(100 \mu \mathrm{l})$ and then allowed to stand for 10 minutes in ice water. After centrifuging $(10,000 \mathrm{rpm}, 3$ minutes), the supernatant $(140 \mu \mathrm{l})$ was incubated with $p$-dimethylaminobenzaldehyde solution $(300 \mu \mathrm{l})$ at $37^{\circ} \mathrm{C}$ for 20 minutes. After 20 minutes, the color reaction was detected by the absorbance at $585 \mathrm{~nm}$ with a microplate reader Bio-Rad Model 550.

Test samples were replaced with the buffer solution for the control, while the enzyme solution was replaced with the buffer solution for the blank. Percent inhibition was calculated as follows: Inhibition $(\%)=[(\mathrm{A}-\mathrm{B})-$ $(\mathrm{C}-\mathrm{D})] /(\mathrm{A}-\mathrm{B}) \times 100$. A, control OD; B, control blank OD;C, sample OD; D, sample blank OD.

The $50 \%$ inhibitory concentration $\left(\mathrm{IC}_{50}\right)$ was calculated using the mean of 3 observation at each of the 5 concentrations.

Acknowledgements We are grateful to Miss N. Kobayashi, Dr. M. Ikegami and Dr. H. Kasai and of Hoshi University for NMR and mass measurements.

References

1. Laurent TC, Fraser JRE. Hyaluronan. FASEB J 6: 2397-2405 (1992)

2. Alexander B, Daniel JR, Stephan B, Masatoshi N, Sumnhild S, Julia H, Günther B, Stefan D, Mark JJ, Armin B. LAscorbic acid 6-hexadecanoate, a potent hyaluronidase inhibitor. J Biol Chem 44: 45990-45997 (2004)

3. Wat C-K, Neil Towers GH. Production of methylated phenolic acids by species of Lentinus (Bashidiomysete). Phytochem 16: 290-291 (1977)

4. Chu M, Mierzwa R, Xu L, He L, Terracciano J, Patel M, Zhao W, Black TA, Chan T-M. Structure of Sch 419560, a novel $\alpha$-pyrone antibiotic produced by Pseudomonas fluorescens. J Antibiot 55: 215-218 (2002)

5. Kobayashi M, Matsushita H, Yoshida K, Tsukiyama R, Sugiyama $\mathrm{T}$, Yamamoto $\mathrm{K}$. In vitro and in vivo antiallergenic activity of soy sauce. Inter J Molec Medicine 14: 879-884 (2004)

6. Fujitani N, Sakaki S, Yamaguchi Y, Takenaka H. Inhibitory effects of microalgae on the activation of hyaluronidase. J Appl Physiol 13: 489-492 (2000)

7. Spickenreiter M, Braun S, Bernhardt G, Dove S, Buschauer A. Novel 6-O-acylated vitamin $\mathrm{C}$ derivatives as hyaluronidase inhibitors with selectivity for bacterial lyases. Bioorg Med Chem Lett 16: 5313-5316 (2006) 